\title{
COMPOSITION OF FOREST STANDS USED BY WHITE-HEADED WOODPECKERS FOR NESTING IN WASHINGTON
}

\author{
Jeffrey M. Kozmal
}

\begin{abstract}
In this study, I examined the composition of managed ponderosa pine (Pinus ponderosa) forests used by nesting White-headed Woodpeckers (Picoides albolarvatus) along the eastern slope of the Cascade Range in Washington. I sampled trees and snags using the point-centered quarter method to assess species composition, tree and snag density, and stand basal area in 16 forest stands containing White-headed Woodpecker nests. All stands had a history of timber management and 2 had been burned and salvage-logged. Mean live-tree density $(\geq 10.16 \mathrm{~cm} \mathrm{dbh})$ was 182.3 trees $\cdot \mathrm{ha}^{-1}(\mathrm{SE}=13.52)$, mean snag density $(\geq 10.16 \mathrm{~cm} \mathrm{dbh})$ was 11.5 snags $\cdot \mathrm{ha}^{-1}(\mathrm{SE}=1.92)$, and mean stand basal area was $17.2 \mathrm{~m}^{2} \cdot \mathrm{ha}^{-1}(\mathrm{SE}=$ 1.58). Ponderosa pine had the highest importance value $(\bar{x}=220.9, \mathrm{SE}=17.25)$ of any tree species in all but 2 stands. Mean dbh of ponderosa pines was $33.0 \mathrm{~cm}(\mathrm{SE}=0.26)$ and ranged from 26.1 to $50.2 \mathrm{~cm}$ within stands. Mean density of ponderosa pine was greatest in the $20.3-30.5 \mathrm{~cm}$ dbh size class and lowest in the $50.8-61.0 \mathrm{~cm}$ and $>61.0 \mathrm{~cm}$ dbh size classes. Tree density was up to 5.3 times greater than densities believed to be typical of ponderosa pine forests prior to fire suppression. Snag densities were within the range estimated for historical dry forests of the eastern Cascades, yet only $50 \%$ of all snags sampled had a dbh $>25.4 \mathrm{~cm}$. Although White-headed Woodpeckers are considered strongly associated with old-growth ponderosa pine, my results suggest that they may be more adaptable to using forests dominated by smaller diameter trees.
\end{abstract}

REsumen.-En este estudio, examiné la composición de los bosques manejados de pino ponderosa (Pinus ponderosa), utilizados para anidamiento por el pájaro carpintero cabeciblanco (Picoides albolarvatus), a lo largo de la vertiente oriental de la cordillera Cascade del Estado de Washington. Muestreé árboles vivos y muertos usando el método de cuadrantes al punto central en 16 rodales con nidos del pájaro carpintero cabeciblanco para evaluar la composición de especies, la densidad de árboles vivos y muertos y el área basal del rodal. Todas las áreas tenían una historia de manejo maderable y 2 habían sido quemadas y taladas para recuperar madera. La densidad promedio de árboles vivos ( $\geq 10.16 \mathrm{~cm}$ DAP) fue 182.3 árboles $\cdot \mathrm{ha}^{-1}$ $(\mathrm{DE}=13.52)$, la densidad promedio de árboles muertos $(\geq 10.16 \mathrm{~cm} \mathrm{DAP})$ fue 11.5 árboles muertos $\cdot \mathrm{ha}^{-1}(\mathrm{DE}=1.92) \mathrm{y}$ el área basal promedio de los rodales fue $17.2 \mathrm{~m}^{2} \cdot \mathrm{ha}^{-1}(\mathrm{DE}=1.58)$. El pino ponderosa tuvo el valor de importancia más alto $(\bar{x}=220.9, \mathrm{DE}=17.25)$ de las especies de árboles en todos, menos 2 rodales. El DAP promedio de los pinos ponderosa fue $33.0 \mathrm{~cm}(\mathrm{DE}=0.26)$ y variaba de 26.1 a $50.2 \mathrm{~cm}$ dentro de rodales. La densidad promedio del pino ponderosa fue la mayor en la clase de 20.3-30.5 cm DAP y menor de las clases de 50.8-61.0 cm y $>61.0 \mathrm{~cm}$ DAP. La densidad de árboles fue hasta 5.3 veces mayor que las consideradas típicas para bosques de pino ponderosa antes de la intervención para prevenir incendios. Las densidades de árboles muertos estuvo dentro del rango estimado para los bosques secos históricos del oriente de la cordillera Cascade, no obstante sólo $50 \%$ de los árboles muertos muestreados tuvieron un DAP $>25.4 \mathrm{~cm}$. Aunque se considera que los pájaros carpinteros cabeciblancos están estrechamente asociados con bosques primarios de pino ponderosa, mis resultados sugieren que podrían ser más adaptados a usar bosques donde predominan árboles de diámetro menor.

The White-headed Woodpecker (Picoides albolarvatus) is a primary excavator that occurs in pine- (Pinus spp.) dominated habitats throughout its geographic distribution (Garrett et al. 1996). It is one of the least studied woodpeckers in North America (Garrett et al. 1996), with most previous research focusing on nest site characteristics (Raphael and White 1984, Milne and Hejl 1989, Dixon 1995, Buchanan et al. 2003, Kozma 2009) or foraging behavior (Koch et al. 1970, Ligon 1973, Raphael and White 1984, Morrison and With 1987, Kozma 2010). Only one study has attempted to describe habitat used by White-headed Woodpeckers at the landscape level. Dixon (1995) found that White-headed Woodpecker home ranges in central Oregon were dominated by old-growth ponderosa pine (Pinus ponderosa; 10 trees $>53 \mathrm{~cm}$ dbh per 0.4 ha or 2 trees $>79 \mathrm{~cm}$ dbh per $0.4 \mathrm{ha}$ ) and that home ranges containing predominantly oldgrowth ponderosa pine were smaller than home ranges on fragmented sites that contained a mosaic of all ages of conifer forest. Dixon (1995) concluded that landscapes containing $<26 \%$ old-growth ponderosa pine are not capable of supporting White-headed Woodpeckers. Similarly, George et al. (2005) found that Whiteheaded Woodpeckers in northeastern California

${ }^{1}$ Yakama Nation, Timber, Fish and Wildlife/Fisheries Resource Management, Box 151, Toppenish, WA 98948. E-mail: kozj@yakamafish-nsn.gov 
were absent from 80-year-old, second-growth ponderosa pine, and were only detected in ponderosa pine-dominated forest with a scattered overstory of 300- to 700-year-old trees.

Throughout the interior Pacific Northwest, the White-headed Woodpecker is historically associated with large-diameter ponderosa pine forests (Buchanan et al. 2003). Historic ponderosa pine forests averaged 50 trees $\cdot \mathrm{ha}^{-1}$ with the majority of trees being $60-70 \mathrm{~cm}$ dbh. These forests were maintained by frequent fires that occurred every 5-15 years (Agee 1996, Gaines et al. 2007). Old trees ( $>150$ years) in these historic forests were 40-91 cm dbh and ranged in density from 19 to 49 per hectare (Franklin et al. 2008). Effective fire exclusion, as well as a long period of selective logging of large trees (Arno 1996, Hessburg et al. 2005), has dramatically changed the structure and species composition of modern-day ponderosa pine forests. Today, ponderosa pine forests have 3-10 times the density of trees compared to historic conditions, with the majority of trees being $20-30 \mathrm{~cm}$ dbh (Harrod et al. 1999). Old forests dominated by widely spaced, large ponderosa pine are now a minor or missing landscape component, and many dry forest landscapes contain few or no old forest structures (Franklin et al. 2008). Determining the composition of modern-day ponderosa pine forests occupied by White-headed Woodpeckers will aid our understanding of the habitat used by this species and may inform projects designed to restore ponderosa pine forests.

This study evaluates tree characteristics, tree species composition, and overall structure of dry forests used by White-headed Woodpeckers for nesting. Specifically, my objectives were to determine (1) the overall density of trees and snags, and basal area for sites occupied by nesting White-headed Woodpeckers; (2) the density of trees and snags by dbh class, with emphasis on the density of large-diameter trees $(>50.8 \mathrm{~cm}$ $\mathrm{dbh}$ ); and (3) the species composition and importance value for each tree species.

\section{Study AREA}

I conducted this study within 4 areas along the eastern slope of the Cascade Range in southern Kittitas, Yakima, and northern Klickitat counties, Washington, from 2005 to 2009 (Fig. 1). The topography of the eastern slope of the Cascades is complex with intermixed slopes (Everett et al. 2000). The climate is characterized by dry, hot summers, with over $80 \%$ of the annual precipitation falling as snow during winter (Wright and Agee 2004). My study sites were located in the Okanogan-Wenatchee National Forest and on lands owned by the Washington Department of Natural Resources and 3 private landowners.

The overstory of the study area contained a mix of tree species including ponderosa pine, Douglas-fir (Pseudotsuga menziesii), western larch (Larix occidentalis), grand fir (Abies grandis), and quaking aspen (Populus tremuloides), depending upon site history, elevation, and slope. The understory was dominated by snowbrush ceanothus (Ceanothus velutinus), antelope bitterbrush (Purshia tridentata), wax currant (Ribes cereum), common snowberry (Symphoricarpos albus), and Douglas spirea (Spirea douglasii). Overall, the area is characterized as a mixture of the "hot dry shrub/herb" (ponderosa pine/bitterbrush/bluebunch wheatgrass [Agropyron spicatum]) and "warm dry shrub/herb" (Douglas-fir/ bitterbrush/bluebunch wheatgrass) vegetation types (Harrod et al. 1999).

\section{Methods}

White-headed Woodpeckers are uncommon in my study area and can be difficult to detect. Therefore, I selected sites opportunistically if White-headed Woodpeckers were encountered during reviews of proposed timber harvests and by reviewing a historical sightings database of White-headed Woodpecker locations maintained by the Washington Department of Fish and Wildlife. I sampled 16 sites within the 4 study areas. Each site contained a breeding pair of White-headed Woodpeckers and one active nest during at least one year of the study. Fourteen sites were unburned and had experienced timber harvest within the previous 15 years, and 2 sites had burned and were subsequently salvage-harvested. Seven of the unburned sites were managed by thinning from below where multiple harvests removed dominant and codominant trees resulting in evenly spaced trees with a similar dbh. The other 7 sites were managed by precommercial thinning, where smalldiameter understory trees were removed while leaving a majority of the larger diameter trees. Both burned sites resulted from low- to moderate-intensity fires that primarily removed understory vegetation and scattered intermediate trees. Elevation of sites ranged from 560 to $1150 \mathrm{~m}$.

I searched for White-headed Woodpecker nests beginning in early May and continuing 


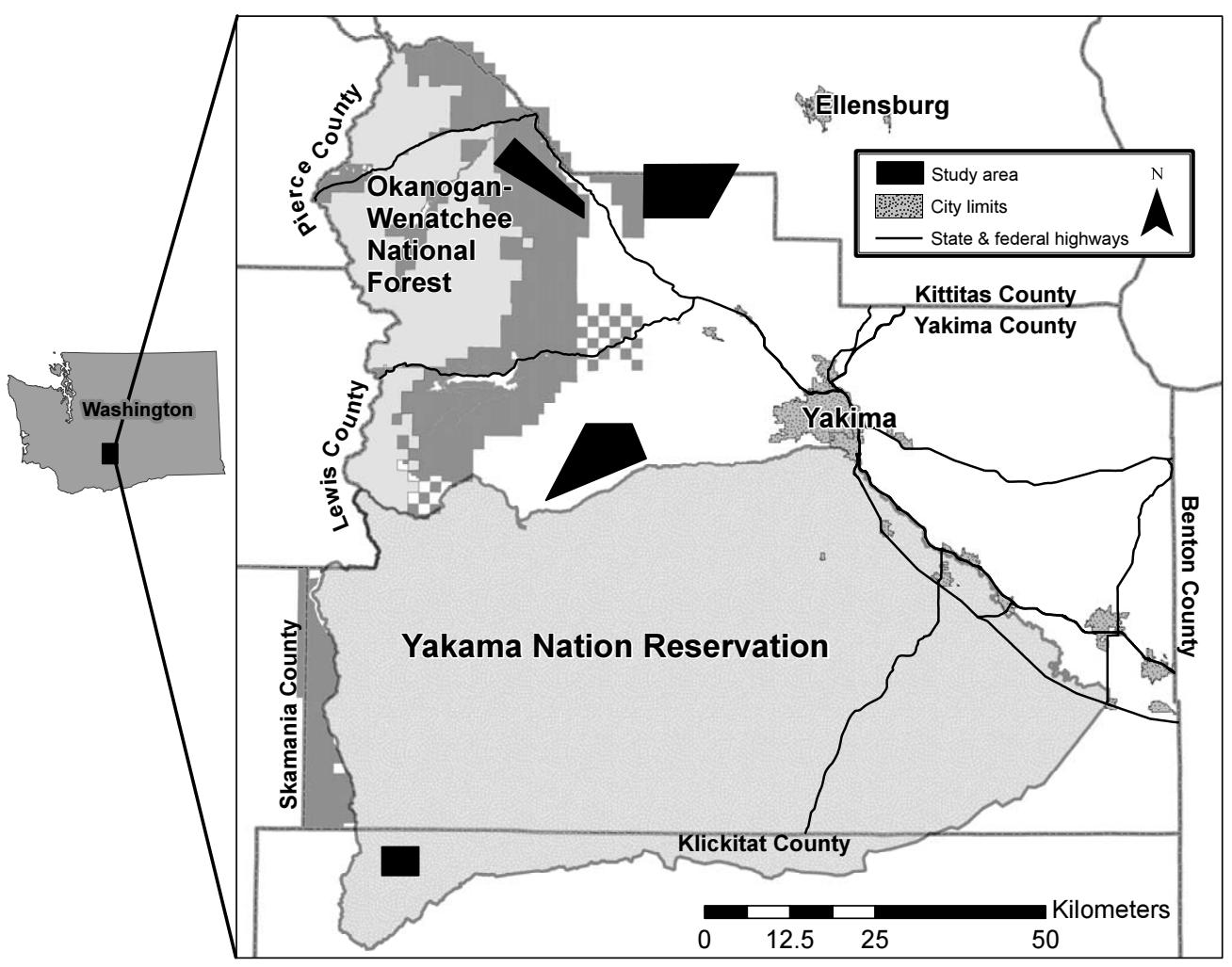

Fig. 1. Study areas containing forest stands used for nesting by White-headed Woodpeckers in Kittitas, Yakima, and Klickitat counties, Washington, 2005-2009.

until early July. Because of time constraints, only a subset of the 16 sites were searched in each year, and sites searched within a given year were searched at least once every $7-10$ days, resulting in approximately equal search effort. To more easily find nests, I used recordings of woodpecker calls and drummings (Johnson et al. 1981, Melletti and Penteriani 2003) broadcasted from a portable MP3 player attached to a miniamplifier speaker (RadioShack Corporation, Fort Worth, TX) to locate woodpeckers on known and suspected breeding territories (Nappi and Drapeau 2009). Because males and females both take part in cavity excavation and incubation, I followed adult birds of either sex during the nesting season to find cavities. If following birds failed to result in locating a cavity, I relied on adults carrying food, adult distress calls, or sounds of begging chicks to reveal the cavity location. I examined all cavities with a Tree Top Peeper IV nest inspection system (Sandpiper Technologies, Inc., Manteca, CA), which is similar to the system described by Richardson et al.
(1999), to confirm if nests found during excavation were active (presence of eggs or young). I recorded the location of all active nests with a handheld GPS.

I downloaded all active nest locations to a topographic mapping program (Terrain Navigator Pro 2005) and estimated nesting area boundaries (hereafter nest stand) by placing a 500-meterradius circle (i.e., sampling window) around each nest site. This equates to a 78.5-ha area per nest site, which is similar to the 63-ha mean individual White-headed Woodpecker summer homerange estimate for fragmented sites in central Oregon (Dixon 1995). To further define the nest stand, I drew a line around the forested area contained within the sampling window (one or more circles depending on the number of nests recorded per nesting area) and then estimated the total forest area. Nonforested areas (e.g., unforested lithosols, shrubsteppe, etc.) were subtracted from the area estimation. This resulted in a mean forested area per nest stand of 68.2 ha (95\% confidence interval [CI]: 55.2, 81.1). 
Within each nest stand, I randomly located starting points for 4-7 transects, depending on size of the nest stand, to conduct point-centered quarter (PCQ) sampling (Cottam and Curtis 1956). The mean distance of transect starting points from a nest site was $285.1 \mathrm{~m}(n=194$, 95\% CI: $261.7,308.6)$. This is closer than the mean maximum distance of $390 \mathrm{~m}(n=15,95 \%$ CI: $297.7,481.9)$ that I have observed Whiteheaded Woodpeckers foraging from active nests. Each transect consisted of 10 sampling points, resulting in 40-70 sampling points per stand and 0.3-1.4 points per hectare. This protocol samples 2-3.5 times more points than recommended by Cottam and Curtis (1956) but results in more precise estimates of density and basal area (Bryant et al. 2004). A random compass bearing was assigned to each PCQ transect to determine the direction it would follow from the starting point. If the transect had the chance of intersecting another transect, a new bearing was randomly assigned until no transects intersected to avoid double sampling trees. The first sampling point was located $10 \mathrm{~m}$ from the initial start of the transect, with subsequent points at $10-\mathrm{m}$ intervals. However, if subsequent points contained a previously sampled tree or snag $(\geq 10.16$ $\mathrm{cm} \mathrm{dbh}$ ), I continued moving at 5-m increments along the transect until trees were no longer at risk of double sampling. This helped me avoid having to correct for many empty quadrants and resulted in transects ranging in length from 100 to $220 \mathrm{~m}$. From the PCQ sampling, I calculated mean tree and snag dbh, tree and snag density, and stand basal area (Stauffer and Best 1980, Manuwal 1983). I calculated importance values for each tree species by summing the relative density, relative cover, and relative frequency (Curtis and McIntosh 1951).

\section{RESUlTS}

Tree species composition was similar across all nest stands used by White-headed Woodpeckers. Ponderosa pine was the most abundant tree species in all but 3 of the 16 nest stands. The percentage of ponderosa pine in each nest stand ranged from $33 \%$ to $100 \%$, with 12 stands consisting of more than $75 \%$ ponderosa pine.

Mean tree and snag density were highly variable between nest stands. Mean live-tree density was 182.3 trees $\cdot \mathrm{ha}^{-1}(\mathrm{SE}=13.52$, range 68.7-267.3) and mean snag density was 11.5 snags $\cdot \mathrm{ha}^{-1}(\mathrm{SE}=1.92$, range 1.4-26.9). Mean density of all trees was highest in the 20.3-30.5 $\mathrm{cm}$ and 30.6-40.6 $\mathrm{cm}$ dbh classes and lowest in the $50.8-61.0 \mathrm{~cm}$ and $>61.0 \mathrm{~cm}$ dbh classes (Fig. 2). Mean snag density was highest in the 2 smallest dbh classes and lowest in the largest dbh class (Fig. 2). Nest stand basal area was also variable, with a mean of $17.2 \mathrm{~m}^{2} \cdot \mathrm{ha}^{-1}(\mathrm{SE}=$ 1.58 , range 10.1-31.7). Ponderosa pine was the only tree species detected in 4 nest stands, and it had the highest importance value $(\bar{x}=220.9$, $\mathrm{SE}=17.25$, range 87.9-293.3) of any tree species in all but 2 nest stands. Douglas-fir was the second-most abundant tree species, with a mean importance value of $57.0(\mathrm{SE}=15.71$; range 0.0-188.5).

The size-class distribution of trees and snags was comparable across nest stands. Mean dbh of all ponderosa pine trees was $33.0 \mathrm{~cm}(\mathrm{SE}=0.26)$ and ranged within nest stands from 26.1 to $50.2 \mathrm{~cm}$. Mean density of ponderosa pine was greatest in the $20.3-30.5 \mathrm{~cm}$ and $30.6-40.6 \mathrm{~cm}$ dbh size classes, and lowest in the $50.8-61.0 \mathrm{~cm}$ and $>61.0 \mathrm{~cm}$ dbh size classes (Fig 3). Mean dbh of all other conifers was $38.8 \mathrm{~cm}$ ( $\mathrm{SE}=$ 0.55 ) and ranged within nest stands from 12.2 to $48.8 \mathrm{~cm}$. Mean density of all other conifer trees was greatest in the $30.5-40.6 \mathrm{~cm}$ and $40.7-50.8 \mathrm{~cm}$ dbh size classes, and lowest in the smallest and largest size classes (Fig. 3). Mean $\mathrm{dbh}$ of snags was $26.0 \mathrm{~cm}(\mathrm{SE}=0.72)$ and ranged within nest stands from 15.7 to $30.3 \mathrm{~cm}$.

\section{DisCUSSION}

This study is the first to report on characteristics of forest stands used by White-headed Woodpeckers for nesting in Washington. Previous studies have found the White-headed Woodpecker to be associated with old-growth or large-diameter ponderosa pine in the vicinity of nest sites in Washington (Buchanan et. al. 2003) and California (Raphael and White 1984, Milne and Hejl 1989) and at the home-range scale in Oregon (Dixon 1995). Buchanan et al. (2003) found that White-headed Woodpeckers selected nesting areas that contained more large-diameter trees and snags than found in paired random locations within $1 \mathrm{~km}$ of the nest. In Oregon, when White-headed Woodpeckers inhabited areas containing predominately oldgrowth ponderosa pine $(>53.0 \mathrm{~cm} \mathrm{dbh})$, they had smaller, less variable home-range sizes compared to home ranges that consisted of fragmented mixed conifer sites of a variety of ages 

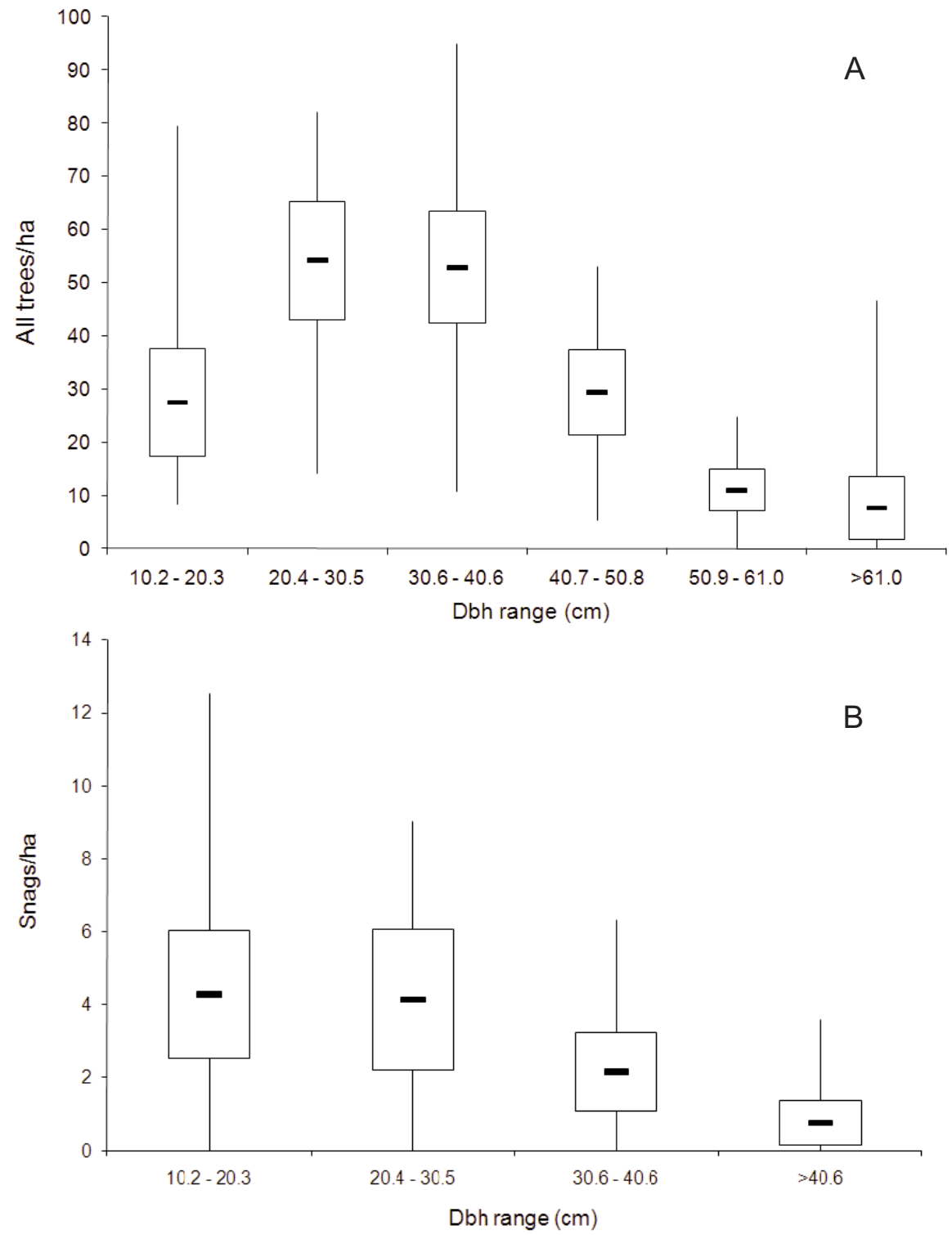

Fig. 2. Box plots showing density of all trees in $6 \mathrm{dbh}$ size classes (A) and all snags in 4 dbh size classes (B) in 16 forest stands used for nesting by White-headed Woodpeckers along the eastern slope of the Cascade Range, Washington, 2005-2009. Each box represents the interquartile range; the upper and lower horizontal lines represent the upper and lower quartile, respectively. The horizontal line within each box represents the mean density per stand. The end points of the lower and upper vertical lines extending from each box represent the minimum and maximum density in that size category, respectively.

(Dixon 1995). Since White-headed Woodpeckers are primarily bark gleaners (Raphael and White 1984) and feed extensively on ponderosa pine seeds throughout winter (Garrett et al. 1996), large-diameter and old-growth ponderosa pines may be comparatively more important to White-headed Woodpeckers because they have greater bark foraging area, higher insect abundance (Raphael and White 1984, Covert-Bratland et al. 2006), and greater and more frequent cone production than small-diameter trees (Krannitz and Duralia 2004).

Contrary to the results of earlier studies documenting the close association of White-headed 

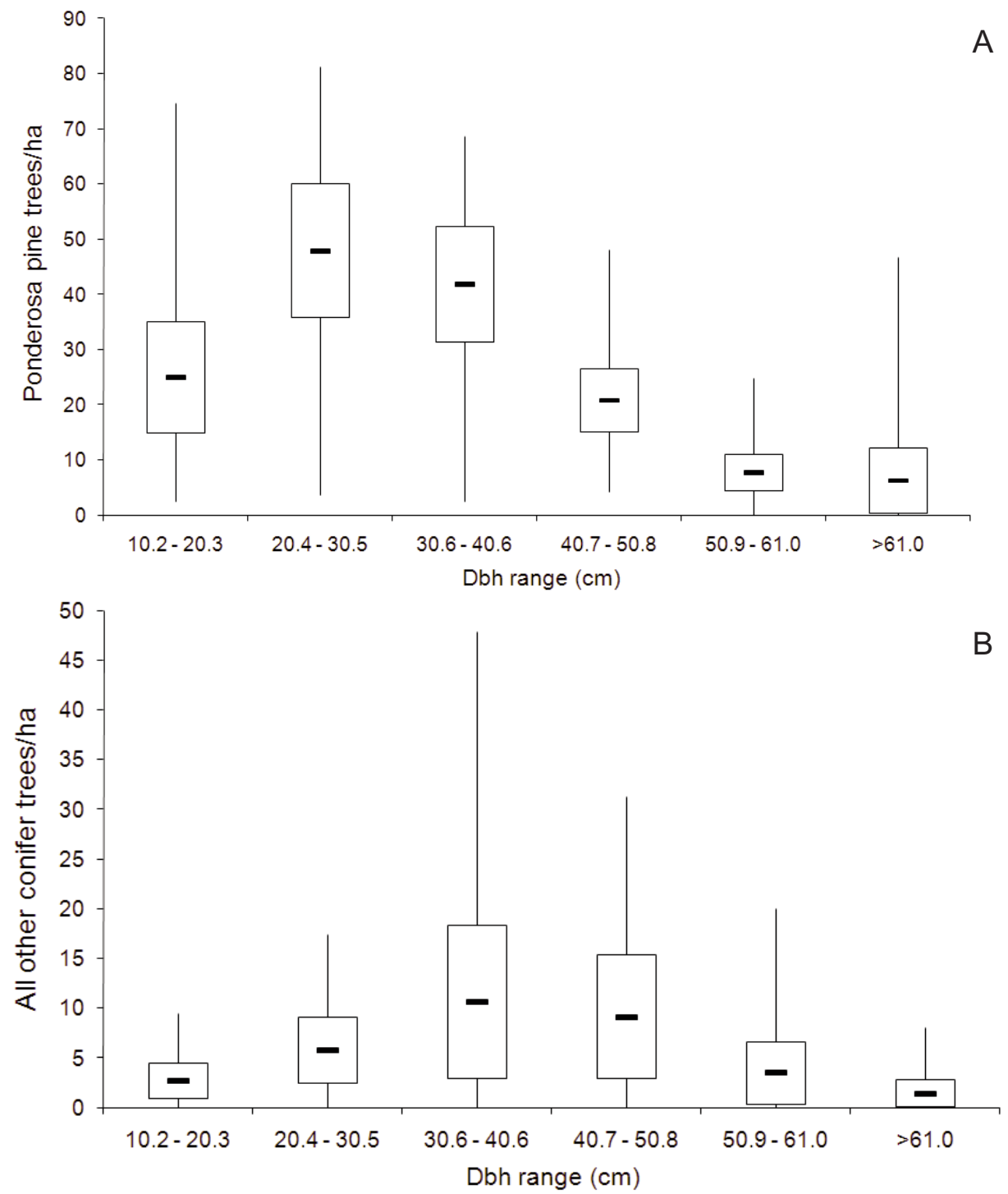

Fig. 3. Box plots showing density of ponderosa pine (A) and all other conifers (B) in 6 dbh classes in 16 forest stands used for nesting by White-headed Woodpeckers along the eastern slope of the Cascade Range, Washington, 2005-2009. Each box represents the interquartile range; the upper and lower horizontal lines represent the upper and lower quartile, respectively. The horizontal line within each box represents the mean density per stand. The end point of the lower and upper vertical lines extending from each box represent the minimum and maximum density in that size category, respectively.

Woodpeckers and old-growth forest structures, nest stands used by White-headed Woodpeckers in this study had low densities of large-diameter $(>50.8 \mathrm{~cm} \mathrm{dbh}$ ) ponderosa pine. The lack of large-diameter ponderosa pine in these nest stands could be attributed to the fact that 12 of the 16 stands I sampled had a long history of management for timber production through which many of the large-diameter ponderosa pines were removed during past timber harvests (Arno 1996, Hessburg et al. 2005). This prevalence of timber harvest differs from the study conducted by Buchanan et al. (2003) where only 4 of the 21 nest locations sampled exhibited signs of past timber harvest. Although I only sampled stands used for nesting, which is a smaller component of an entire home range (Dixon 1995), my results show that White-headed Woodpeckers 
are capable of nesting in areas containing low densities of large-diameter trees. Furthermore, the probability of nest survival within these stands was high $(0.70$ [95\% CI: $0.55,0.82 ; n=$ 55 nests], calculated using the logistic-exposure method, Kozma unpublished data), indicating that White-headed Woodpeckers also reproduce successfully in these nest stands.

The density and size of live trees in my study area differ from those characterizing historic ponderosa pine stands. Historic ponderosa pine forests, maintained by frequent, low-intensity fires, had live-tree densities averaging 50 trees • $\mathrm{ha}^{-1}$ with the majority of trees being $60-70 \mathrm{~cm}$ dbh (Agee 1996, Gaines et al. 2007), and basal areas were thought to be near $21 \mathrm{~m}^{2} \cdot \mathrm{ha}^{-1}$ (summarized in Harrod et al.1998). Similarly, Youngblood et al. (2004) found that upper-canopy ponderosa pine in 3 protected, remnant oldgrowth forests (i.e., most upper-canopy trees $>100$ years old) in Oregon and California, had a mean overall diameter of $60.0 \pm 1.55 \mathrm{~cm} \mathrm{dbh}$ and an overall mean density of $50 \pm 3.5$ trees $\cdot \mathrm{ha}^{-1}$. Nest stands in this study had a mean basal area of $17.2 \mathrm{~m}^{2} \cdot \mathrm{ha}^{-1}$, yet had up to 5.3 times more trees per hectare than historic conditions, with most trees being $20-40 \mathrm{~cm}$ dbh. This is similar to conditions described by Harrod et al. (1999) for modern day ponderosa pine forests experiencing the effects of fire suppression. However, tree density in these nest stands was probably much higher prior to management activities. Through thinning and reduced tree density, nest stands have come closer to resembling pre-European settlement conditions, although without the abundance of dominant large-diameter or old-growth trees in the canopy. Because Whiteheaded Woodpeckers are successfully using these stands for nesting, the stands' role as breeding habitat in conserving populations of this species should be reconsidered.

Snag-retention guidelines for most plant communities in North America range between 1 and 8 snags $\cdot$ ha $^{-1}$ (Hutto 2006). Bull et al. (1997) recommended that 10 snags $\cdot \mathrm{ha}^{-1}$ would support viable populations of cavity-nesting birds in ponderosa pine and mixed conifer forests in the interior Columbia River basin. Based on these recommendations, it appears that snag densities in most nest stands in this study are sufficient to support a nesting pair of White-headed Woodpeckers. However, these results must be viewed with caution. Only 5 of the 16 nest stands contained snag densities within the range estimated for historical dry forests of the eastern Cascades (14.5-34.6 snags $\cdot$ ha $^{-1}$; Harrod et al. 1998), and only $50 \%$ of snags encountered are considered a suitable size for nesting ( $\mathrm{dbh}>25.4 \mathrm{~cm} ; 87 \%$ of snags used for nesting in this area were $>25.4 \mathrm{~cm} \mathrm{dbh}$ ). The largest snags in this study were mostly remnants from previous harvests. These snags will eventually be lost and most likely will not be replaced using current management practices that optimize timber production (Ohmann et al. 1994).

White-headed Woodpeckers rely primarily on snags for constructing nest cavities (Buchanan et al. 2003, Kozma 2009); they tend to choose large-diameter snags when available (Raphael and White 1984, Milne and Hejl 1989); and they rarely excavate a second cavity in a snag they used for a previous nest attempt (Kozma personal observation). Likewise, largediameter snags are often selected by other cavity-nesting species for creating cavities (Bunnell et al. 2002, Ganey and Vojta 2004, Spiering and Knight 2005) because they stand longer (Parks et al. 1999) and the cavities tend to be safer from predators and maintain a more stable temperature (Lundquist and Mariani 1991, Christman and Dhondt 1997). Therefore, having a sufficient supply of adequate snags is important for limiting competition with other cavity-nesting species and maintaining conditions necessary for the persistence of reproducing White-headed Woodpeckers. The lack of large-diameter live ponderosa pines in these managed forests indicates that current forest management practices are influencing the future recruitment of largediameter trees and snags (Bagne et al. 2008), which could have negative long-term effects on certain seed-eating species and the cavity-nesting bird community. In order to place current forest conditions on a trajectory toward historic conditions, it is important for land managers to retain remnant large-diameter live and dead ponderosa pines (i.e., legacy trees) to improve the future availability of large trees and snags for cavity-nesting species (Buchanan 2009). However, to be most effective, conservation measures and active forest management have to be implemented not only at the stand level but also at the landscape level (Franklin et al. 2008, Buchanan 2009).

The results of this study demonstrate that White-headed Woodpeckers are capable of nesting in ponderosa pine forests with a small component of large-diameter trees. This result 
suggests that this woodpecker may be more tolerant of younger forest conditions than previously thought. However, there is still much that is unknown about the effects of young ponderosa pine forests on White-headed Woodpecker ecology. Future research on White-headed Woodpeckers in mid-seral forests (51-149 years old, mean tree dbh 23-52 cm; Dixon 1995) should focus on home-range size, habitat use within home ranges, age of birds and their longevity, and measurements of food availability and its influence on overwinter survival. Land managers need to focus on preserving the largestdiameter live trees and snags in managed stands to maintain future foraging and nesting sites for seed-eating and cavity-nesting animals.

\section{ACKNOWLEDGMENTS}

I thank T. Strelow for her assistance with monitoring nests and collecting PCQ data during the 2008 nesting season. The Washington Department of Natural Resources, Western Pacific Timber Company, R. Matson, and C. Coffin provided access to their lands. Funding was provided by the Bureau of Indian Affairs. I also thank J. Matthews, J. Buchanan, and 2 anonymous reviewers for helpful comments on earlier versions of this manuscript.

\section{Literature Cited}

AGEE, J.K. 1996. Achieving conservation biology objectives with fire in the Pacific Northwest. Weed Technology 10:417-421.

ARNO, S.F. 1996. The concept: restoring ecological structure and process in ponderosa pine forests. Pages 37-38 in C.C. Hardy and S.F. Arno, editors, The use of fire in forest restoration. General Technical Report INT-GTR341, USDA Forest Service, Ogden, UT.

Bagne, K.E., K.L. Purcell, and J.T. Rotenberry. 2008. Prescribed fire, snag population dynamics, and avian nest site selection. Forest Ecology and Management 255:99-105.

Bryant, D.M., M.J. Ducey, J.C. Innes, T.D. LeE, R.T. ECKERT, AND D.J. ZaRIN. 2004. Forest community analysis and the point-centered quarter method. Plant Ecology 175:193-203.

BuCHANAN, J.B. 2009. Balancing competing habitat management needs for Northern Spotted Owls and other bird species in dry forest landscapes. Pages 109-117 in T.D. Rich, C. Arizmendi, D. Demarest, and C. Thompson, editors, Tundra to tropics: connecting birds, habitats and people. Proceedings of the 4th International Partners in Flight Conference, McAllen, TX.

Buchanan, J.B., R.E. Rogers, D.J. Pierce, and J.E. JacobSON. 2003. Nest-site habitat use by White-headed Woodpeckers in the eastern Cascade Mountains, Washington. Northwestern Naturalist 84:119-128.
Bull, E.L., C.G. Parks, and T.R. Torgersen. 1997. Trees and logs important to wildlife in the interior Columbia River basin. General Technical Report PNW-GTR391, USDA Forest Service, Portland, OR.

Bunnell, F.L., E. Wind, M. Boyland, AND I. Houde. 2002. Diameters and heights of trees with cavities: their implications to management. Pages 717-737 in W.F. Laudenslayer Jr., P.J. Shea, B.E. Valentine, C.P. Weatherspoon, and T.E. Lisle, technical coordinators, The ecology and management of dead wood in western forests: a symposium. General Technical Report PSWGTR-181, USDA Forest Service, Albany, CA.

Christman, B.J., AND A.A. DhOndT. 1997. Nest predation in Black-capped Chickadees: how safe are cavity nests? Auk 114:769-773.

Cottam, G., And J.T. Curtis. 1956. The use of distance measures in phytosociological sampling. Ecology 37 : 451-460.

Covert-Bratland, K.A., W.M. Block, and T.C. Theimer. 2006. Hairy Woodpecker winter ecology in ponderosa pine forests representing different ages since wildfire. Journal of Wildlife Management 70:1379-1392.

CurTis, J.T., And R.P. McInTosh. 1951. An upland forest continuum in the prairie-forest border region of Wisconsin. Ecology 32:476-496.

DixON, R.D. 1995. Ecology of White-headed Woodpeckers in the central Oregon Cascades. Master's thesis, University of Idaho, Moscow, ID.

Everett, R.L., R. SchellhaAs, R.D. Keenum, D. Spurbeck, AND P. OHLSON. 2000. Fire history in the ponderosa pine/Douglas-fir forests on the east slope of the Washington Cascades. Forest Ecology and Management 129:207-225.

Franklin, J.F., M.A. Hermstrom, R. Van Pelt, and J.B. BUCHANAN. 2008. The case for active management of dry forest types in eastern Washington: perpetuating and creating old forest structures and functions. Washington Department of Natural Resources, Olympia, WA.

Gaines, W.L., M. Haggard, J.F. Lehmkuhl, A.L. Lyons, AND R.J. HARROD. 2007. Short-term response of land birds to ponderosa pine restoration. Restoration Ecology 15:670-678.

GANEY, J.L., AND S.C. VOJTA. 2004. Characteristics of snags containing excavated cavities in northern Arizona mixed-conifer and ponderosa pine forests. Forest Ecology and Management 199:323-332.

Garkett, K.L., M.G. Raphael, and R.D. Dixon. 1996. White-headed Woodpecker (Picoides albolarvatus). No. 252 in A. Poole and F. Gill, editors, The birds of North America. American Ornithologists' Union, Philadelphia, PA.

George, T.L., S. Zack, W.F. Laudenslayer Jr. 2005. A comparison of bird species composition and abundance between late- and mid-seral ponderosa pine forests. Pages 159-169 in Proceedings of the 2002 Fire Conference: managing fire and fuels in the remaining wildlands and open spaces of the southwestern United States. General Technical Report PSW-GTR-198, USDA Forest Service, Albany, CA.

Harrod, R.J., W.L. GaInes, W.E. HarTL, AND A. CAMP. 1998 Estimating historical snag density in dry forests east of the Cascade Range. General Technical Report PNW-GTR-428, USDA Forest Service, Portland, OR.

Harrod, R.J., B.H. McRaE, and W.E. HaRTL. 1999. Historical stand reconstruction in ponderosa pine forests to guide silvicultural prescriptions. Forest Ecology and Management 114:433-446. 
Hessburg, P.F., J.K. Agee, and J.F. Franklin. 2005. Dry forests and wildland fires of the inland Northwest USA: contrasting the landscape ecology of the pre-settlement and modern eras. Forest Ecology and Management 211:117-139.

HutTo, R.L. 2006. Toward meaningful snag-management guidelines for postfire salvage logging in North American conifer forests. Conservation Biology 20:984-993.

Johnson, R.R., B.T. Brown, L.T. Haight, AND J.M. Simpson. 1981. Playback recordings as a special avian censusing technique. Studies in Avian Biology 6:68-75.

Koch, R.F., A.E. Courchesne, and C.T. Collins. 1970. Sexual differences in foraging behavior of Whiteheaded Woodpeckers. Bulletin of the Southern California Academy of Sciences 69:60-64.

Kozma, J.M. 2010. Characteristics of trees used by Whiteheaded Woodpeckers for sap feeding in Washington. Northwestern Naturalist 91:81-86.

2009. Nest-site attributes and reproductive success of White-headed and Hairy Woodpeckers along the east-slope Cascades of Washington State. Pages 52-61 in T.D. Rich, C. Arizmendi, D. Demarest, and C. Thompson, editors, Tundra to tropics: connecting birds, habitats and people. Proceedings of the 4th International Partners in Flight Conference, McAllen, TX.

Krannitz, P.G., and T.E. Duralia. 2004. Cone and seed production in Pinus ponderosa: a review. Western North American Naturalist 64:208-218.

LigON, J.D. 1973. Foraging behavior of the White-headed Woodpecker in Idaho. Auk 90:862-869.

LundQuist, R.W., AND J.M. MaRIanI. 1991. Nesting habitat and abundance of snag-dependent birds in the southern Washington Cascade Range. Pages 221-240 in L.F. Ruggiero, K.B. Aubry, B. Keith, A.B. Carey, and M.H. Huff, technical coordinators, Wildlife and vegetation of unmanaged Douglas-fir forest. General Technical Report PNW-GTR-285, USDA Forest Service, Portland, OR.

MANuwal, D.A. 1983. Avian abundance and guild structure in two Montana coniferous forests. Murrelet 64:1-11.

Melletti, M., and V. Penteriani. 2003. Nesting and feeding tree selection in the endangered White-backed Woodpecker, Dendrocopos leucotos lilfordi. Wilson Bulletin 115:299-306.

MiLne, K.A., AND S.J. HeJl. 1989. Nest-site characteristics of White-headed Woodpeckers. Journal of Wildlife Management 53:50-55.
Morrison, M.L., AND K.A. With. 1987. Interseasonal and intersexual resource partitioning in Hairy and Whiteheaded Woodpeckers. Auk 104:225-233.

NAPPI, A., AND P. DRAPEAU. 2009. Reproductive success of the Black-backed Woodpecker (Picoides arcticus) in burned boreal forests: are burns source habitats? Biological Conservation 142:1381-1391.

Ohmann, J.L., W.C. McComb, and A.A. Zumrawi. 1994. Snag abundance for primary cavity-nesting birds on nonfederal forest lands in Oregon and Washington. Wildlife Society Bulletin 22:607-620.

Parks, C.G., D.A. Conklin, L. Bednar, and H. Maffei. 1999. Woodpecker use and fall rates of snags created by killing ponderosa pine infected with dwarf mistletoe. Research Paper PNW-RP-515, USDA Forest Service, Portland, OR.

Raphael, M.G., and M. White. 1984. Use of snags by cavity-nesting birds in the Sierra Nevada. Wildlife Monographs 86:1-66.

Richardson, D.M., J.W. Bradford, P.G. Range, and J. Christensen. 1999. A video probe system to inspect Red-cockaded Woodpecker cavities. Wildlife Society Bulletin 27:353-356.

Spiering, D.J., AND R.L. KNight. 2005. Snag density and use by cavity-nesting birds in managed stands of the Black Hills National Forest. Forest Ecology and Management 214:40-52.

Stauffer, D.F., and L.B. Best. 1980. Habitat selection by birds of riparian communities: evaluating effects of habitat alterations. Journal of Wildlife Management 44:1-15.

Terrain Navigator Pro. 2005. Terrain Navigator Pro user's guide. Version 6.04a. Maptech, Inc., Amesbury, MA.

Wright, C.S., AND J.K. AgEe. 2004. Fire and vegetation history in the eastern Cascade Mountains, Washington. Ecological Applications 14:443-459.

YoungbloOD, A., T. MAX, AND K. COE. 2004. Stand structure in eastside old-growth ponderosa pine forests of Oregon and northern California. Forest Ecology and Management 199:191-217.

Received 11 March 2010 Accepted 4 August 2010 